\title{
Persepsi Mahasiswa Universitas Muhammadiyah Malang Tentang Kemacetan di Kota Malang
}

\author{
Mochamad Aan Sugiharto \\ Program Studi Sosiologi, Fakultas Ilmu Sosial dan Ilmu Politik, Universitas \\ Muhammadiyah Malang \\ e-mail: aansugiharto@umm.ac.id
}

\begin{abstract}
.
This study intends to determine the perceptions of students at the University of Muhammadiyah Malang about traffic jams in the city of Malang. Malang City was chosen as the research location because Malang City has been known as the City of Education in East Java, one of the reasons is because of the many universities in Malang. University of Muhammadiyah Malang was chosen because of several considerations, one of which is because the location of the campus is located in a location which is currently known as the area with the most traffic jams. The number of students is very large, making Malang City very suitable for obtaining data related to student perceptions of congestion, especially traffic jams that occur in Malang City. The research was conducted using qualitative methods with in-depth interviews with students of the University of Muhammadiyah Malang with the aim of being able to reveal the experiences and knowledge of research subjects related to congestion from which the students' perceptions of congestion can be obtained. The research subjects were selected by students of the University of Muhammadiyah Malang who have been affected by traffic jams in Malang City, namely those who live in Malang City, Malang Regency and Batu City who daily have to travel back and forth (commuter) and pass through congestion points in Malang. the streets of Malang City. The result of this research is that congestion is considered a problem that needs to be resolved, but students feel that they are not the party that must be involved in solving congestion problems. This can be seen from students still using private vehicles even though they know that one of the causes of congestion is the high number of private vehicle use.
\end{abstract}

Kata kunci: Traffic Jams, Kota Malang, University, perception

\section{Pendahuluan}

Bagian terbesar umat manusia di dunia tinggal di kota, dan porsinya akan bertambah lagi seiring dengan berjalannya waktu. Oleh sebab itu, fenomena kota dan masyarakatnya adalah fenomena masyarakat manusia itu sendiri. Karena hampir segala dinamika realitas persoalan suprastruktur sosial, budaya, politik dan agama serta infrastruktur ekonomi umat manusia pada saat ini berpusat di kota. ${ }^{1}$

\footnotetext{
${ }^{1}$ Prof.Dr.Damsar, Pengantar sosiologi perkotaan.2017
}

Kota Malang yang memiliki luas wilayah 145,28 $\mathrm{km}^{2}$ dikenal karena beberapa hal, termasuk dari segi pendidikan. Kota yang menjadi bagian dari Malang Raya (Kabupaten Malang, Kota Malang dan Kota Batu) ini juga dikenal sebagai kota pendidikan karena memiliki banyak Perguruan Tinggi yang lokasinya berdekatan. Setidaknya ada 59 Perguruan Tinggi (4 PTN dan 55 PTS) yang terdapat di Kota Malang yang hanya terdiri dari 5 kecamatan tersebut, 
sehingga lokasi antar Perguruan Tinggi jelas tidak berjauhan. ${ }^{2}$

Memiliki banyak Perguruan Tinggi tentu menguntungkan bagi Kota Malang, salah satunya adalah Kota Malang dikenal juga dengan sebutan Kota Pendidikan di Jawa Timur. ${ }^{3}$ Dengan banyaknya jumlah Perguruan Tinggi yang terdapat di Kota Malang, tentu berdampak pada populasi penduduk. Banyak orang dari luar Kota Malang akan datang ke Kota Malang untuk menempuh pendidikan di banyak Perguruan Tinggi tersebut, baik mereka yang berasal dari Jawa Timur maupun dari luar Jawa Timur, bahkan luar Jawa. Hal tersebut membuat populasi penduduk di Kota Malang meningkat, jumlah kendaraan juga meningkat yang merupakan efek dari jumlah populasi yang meningkat tadi. Kenaikan jumlah kendaraan tersebut tentu salah satunya berasal dari kendaraan milik mahasiswa yang menempuh pendidikan di Perguruan Tinggi yang ada di Kota Malang, salah satunya adalah di Universitas Muhammadiyah Malang. Selama hari aktif perkuliahan, bisa dipastikan tempat parkir kendaraan mahasiswa terutama sepeda motor pasti akan penuh. Hal tersebut membuktikan bahwa kendaraan pribadi masih menjadi alat transportasi pilihan favorit mahasiswa dari dan menuju kampus.

Ketika jumlah kendaraan di suatu daerah meningkat, akan berdampak pada kepadatan lalu lintas. Hal tersebut bisa dilihat dari ketika pada jam-jam sibuk yaitu pada pagi hari yang merupakan jam berangkat bekerja/sekolah dan pada sore hari yang merupakan jam pulang bekerja/sekolah. Pada waktu-waktu tersebut, bisa dilihat terjadinya kepadatan

\footnotetext{
2 https://malangkota.go.id/fasilitas-

daerah/pendidikan/perguruan-tinggi, diakses pada april 2019

${ }^{3}$ Wikipedia.org/wiki/kota_malang, diakses pada April 2019 pukul 14:00
}

lalu-lintas yang diakibatkan banyaknya kendaraan yang melintas di jalanan Kota Malang. Kepadatan tersebut terutama terjadi di titik/jalan yang terdapat Perguruan Tinggi, pusat perkantoran, dan jalan utama Kota Malang yang menghubungkan Kota Malang dengan Kabupaten Malang dan Kota Batu. Sepanjang jalan raya tlogomas dan dinoyo, akan terjadi barisan kendaraan yang sangat panjang terutama ketika memasuki jam pulang kantor/sekolah. Begitu juga di jalan Gajayana, jalan Sukarno Hatta, jalan Veteran dan jalan Ahmad Yani.

Barisan panjang kendaraan pribadi di jalanan Kota Malang bagaimanapun juga merupakan sebuah realitas, khususnya realitas transportasi perkotaan. Realitas tersebut tentu tidak sama antara satu kota dengan kota lainnya, bahkan antara negara satu dengan negara lainnya. Jika mengambil contoh realitas transportasi perkotaan di Jerman yang saling terhubung dengan baik dari segi kualitas moda transportasinya, membuat masyarakatnya untuk terdorong menggunakan moda transportasi publik daripada moda transportasi pribadi. Berbeda dengan di Indonesia yang moda transportasi publiknya masih "memprihatinkan" sehingga berakibat masyarakat yang lebih memilih untuk menggunakan kendaraan pribadi. "memprihatinkan" yang dimaksud di sini adalah belum terintegrasinya secara baik moda transportasi umum satu dengan lainnya.

Selain dari persoalan kondisi moda transportasi publik yang diberikan di atas, lebih jauh Damsar mengatakan 3 alasan mengapa kendaraan pribadi masih dominan di jalanan perkotaan di Indonesia yaitu karena kendaraan pribadi sebagai gaya hidup, kendaraan pribadi sebagai stratifikasi sosial, dan kendaraan pribadi sebagai investasi. 
Realitas di atas membuat kepadatan lalu lintas di jalanan Kota Malang yang pada akhirnya mengakibatkan kemacetan. Menurut Adisasmita, berdasarkan waktu, kemacetan lalu lintas akan mengurangi kelancaran lalu lintas perkotaan, sehingga waktu tempuh perjalanan lebih lama. Berdasarkan biaya, waktu perjalanan lama dan tidak mematikan mesin kendaraan akan mengkonsumsi bahan bakar lebih banyak. Artinya pembelian bahan bakar menjadi lebih. Berdasarkan lingkungan, kemacetan lalu lintas akan menimbulkan polusi udara. ${ }^{4}$

Kemacetan yang biasa terjadi pada pagi dan sore hari tersebut sudah menjadi realitas kehidupan sehari-hari masyarakat Kota Malang, kemacetan seolah sudah menjadi bagian tak terpisahkan dari Kota Malang. Masyarakat Kota Malang, khususnya Mahasiswa telah terbiasa dengan kemacetan yang selalu terjadi. Hampir belum ada mahasiswa yang bergerak maupun bertindak dan mengemukakan gagasan terkait kemacetan yang terjadi, yang artinya mahasiswa sebagai agen perubahan (agent of change) belum melihat kemacetan sebagai suatu masalah yang harus diselesaikan di Kota Malang. Sementara, pembangunan sentra industri, hotel, dan mall terus saja terjadi yang mana hal tersebut tentu saja berdampak pada lalu-lintas yang semakin padat.

Pada kehidupan sehari-hari mahasiswa Universitas Muhammadiyah Malang, kemacetan sudah menjadi bagian dari kehidupan mereka. Realitas kemacetan di jalanan Kota Malang memiliki makna yang subjektif pada setiap individu, dalam hal ini adalah mahasiswa Universitas Muhammadiyah Malang dalam memaknai kemacetan

\footnotetext{
${ }^{4}$ Sakti Adji adisasmita, perencanaan pembangunan transportasi, 2011
}

yang terjadi yang tentu berkaitan dengan stock of knowledge mereka.

Kehidupan sehari-hari telah menyimpan dan menyediakan kenyataan, sekaligus pengetahuan yang membimbing perilaku dalam kehidupan sehari-hari. Kehidupan sehari-hari menampilkan realitas objektif yang ditafsirkan oleh individu/memiliki makna-makna subjektif. Penelitian makna melalui sosiologi pengetahuan, mensyaratkan penekunan pada "realitas" dan "pengetahuan". Dua istilah yang menjadi kunci dari teori konstruksi sosial. Realitas adalah suatu kualitas yang terdapat dalam fenomena-fenomena yang memiliki keberadaan (being) yang tidak tergantung pada kehendak individu manusia. Pengetahuan adalah kepastian bahwa fenomena-fenomena itu nyata (real) dan memiliki karakteristikkarakteristik yang spesifik. Kenyataan sosial adalah hasil (eksternalisasi) dari internalisasi dan objektivasi manusia terhadap pengetahuan dalam kehidupan sehari-hari yang dipengaruhi oleh stock of knowledge (cadangan pengetahuan) yang dimilikinya. Cadangan pengetahuan adalah akumulasi dari common sence knowledge yang merupakan pengetahuan yang dimiliki individu bersama individuindividu lainnya dalam kegiatan rutin yang normal dan sudah jelas dengan sendirinya dalam kehidupan sehari-hari. ${ }^{5}$

Beberapa penelitian terkait dengan kemacetan lalu-lintas pernah dilakukan, seperti yang dilakukan oleh Natalia Niken Ekawati dkk dengan judul Kajian Dampak Pengembangan Pembangunan Kota Malang Terhadap Kemacetan Lalu Lintas (Studi Pada Dinas Perhubungan Kota Malang) dalam Jurnal Administrasi Publik (JAP), Vol. 2, No. 1, Hal. 129-133. Hasil dari penelitian ini adalah kemacetan disebabkan oleh

\footnotetext{
${ }^{5}$ Berger, L peter dan thomas luckmann, tafsir sosial atas kenyataan, risalah tentang sosisologi pengetahuan, 2012.
} 
masyarakat yang lebih memilih menggunakan kendaraan pribadi untuk menunjang aktivitas mereka sehingga pemerintah Kota Malang melalui Dinas Perhubungan Kota Malang membuat kebijakan transportasi jangka panjang melalui strategi manajemen lalu lintas, strategi pengembangan jaringan jalan, dan strategi angkutan umum.

Berikutnya adalah penelitian yang dilakukan oleh Anna Aga Pertiwi dkk dengan judul Pengaruh Keberadaan Parkir dan Pedagang Kaki Lima Terhadap Biaya Kemacetan Dan Polusi Udara di Jalan Kolonel Sugiono Malang yang dimuat dalam Jurnal Rekayasa Sipil / Volume 5, No.3 tahun 2011. Hasil dari penelitian ini adalah kemacetan di jalan Kolonel Sugiono diakibatkan oleh keberadaan parkir liar yang menggunakan bahu jalan dan keberadaan PKL di sepanjang jalan Kolonel Sugiono.

Berikutnya adalah penelitian yang dilakukan oleh Haryono dkk dengan judul Persepsi Masyarakat Tentang Kemacetan Lalu Lintas di Jakarta yang dimuat pada Jurnal Manajemen Transportasi \& Logistik Vol. 05 No. 03, November 2018. Hasil dari penelitian ini adalah kemacetan di jalanan Jakarta disebabkan karena banyaknya jumlah kendaraan pribadi. Masyarakat Kota Jakarta lebih memilih menggunakan kendaraan pribadi karena kendaraan/transportasi umum dinilai tidak efisien, tidak nyaman dan tidak terawatnya sarana transportasi umum yang ada.

Penelitian ini menggunakan pendekatan yang berbeda yaitu dengan cara menggali pengetahuan subjek penelitian yang dalam penelitian ini adalah mahasiswa Universitas Muhammadiyah Malang tentang kemacetan yang terjadi di Kota Malang. Penelitian ini tidak melihat faktor-faktor penyebab kemacetan maupun melihat alasan penggunaan kendaraan pribadi dalam menunjang mobilitas sehari-hari, namun lebih kepada bagaimana subjek penelitian melihat kemacetan ini sebagai realitas kehidupan sehari-hari dengan menggunakan teori konstruksi sosial Peter L Berger. Apakah kemacetan yang selama ini terjadi dilihat sebagai sebuah masalah yang harus diselesaikan ataukah kemacetan ini dilihat sebagai sesuatu yang sudah sewajarnya terjadi di suatu kota termasuk Kota Malang yang terkenal sebagai kota pendidikan.

\section{Metode}

Penelitian persepsi mahasiswa Universitas Muhammadiyah Malang tentang kemacetan Kota Malang menggunakan metode deskriptif untuk mendeksripsikan secara terperinci fenomena kemacetan di jalanan Kota Malang yang menjadi realitas kehidupan mahasiswa Universitas Muhammadiyah Malang. Dengan pendekatan kualitatif, yang merupakan penelitian yang dimaksudkan untuk memahami fenomena tentang apa yang dialami oleh subyek penelitian seperti konstruksi, persepsi, perilaku, dan lain-lain yang diungkapkan secara terperinci oleh subyek penelitian.

Subyek Penelitian pada penelitian ini adalah mahasiswa Universitas Muhammadiyah Malang, terutama mereka yang aktivitas dalam kesehariannya selama ini terkena kemacetan. aktivitas yang dimaksud adalah mereka mengalami kemacetan lalu lintas ketika berangkat atau pulang kuliah, juga ketika melakukan aktivitas lain di luar kampus yang mengharuskan mereka berada di jalanan dan terdampak oleh kemacetan lalu lintas yang terjadi. Subyek penelitian pada penelitian ini ditentukan dengan metode purposive yaitu mahasiswa aktif Universitas Muhammadiyah Malang yang berdomisili di wilayah Kota Malang, Kabupaten Malang dan Kota Batu 
dengan pertimbangan bahwa mahasiswa yang berdomisili di 3 wilayah tersebut melakukan perjalanan pulang pergi (commuter) dalam kesehariannya.

Dalam penelitian ini teknik pengumpulan data menggunakan teknik wawancara mendalam (Depht Interview) kepada mahasiswa Universitas Muhammadiyah yang berdomisili di wilayah Kota Malang, Kabupaten Malang dan Kota Batu guna mendapatkan data yang lengkap mengenai persepsi mereka tentang kemacetan yang terjadi di Kota Malang. Dengan menggunakan metode wawancara mendalam, bisa didapatkan data secara terperinci sesuai dengan pendekatan penelitian yaitu deskriptif. Pendekatan deskriptif akan menguraikan secara terperinci tentang pengetahuan, pengalaman dan segala sesuatu yang ada di dalam pikiran subjek penelitian tentang segala sesuatu yang berhubungan dengan kemacetan. dengan begitu, akan diketahui persepsi mahasiswa terhadap kemacetan di Kota Malang.

\section{Hasil dan Pembahasan}

Penelitian tentang Persepsi Mahasiswa Universitas Muhammadiyah Malang tentang Kemacetan di Kota Malang ini mengambil 10 subjek penelitian dengan metode Purposive dengan kriteria yaitu 1). Mahasiswa aktif Universitas Muhammadiyah Malang, 2). Tinggal di Malang, baik kost maupun rumah sendiri, 3). Terdampak kemacetan ketika beraktifitas baik berangkat maupun puang dari kampus. Dari kriteria tersebut, diperoleh 6 Subjek Penelitian yaitu dari mahasiswa Universitas Muhammadiyah Malang kampus III dan 4 subjek mahasiswa Universitas Muhammadiyah Malang kampus II. Kesepuluh subjek penelitian ini telah memenuhi syarat dari penelitian ini yaitu mahasiswa aktif Universitas Muhammadiyah Malang dan selama kesehariannya berkuliah terimbas kemacetan lalu lintas terutama kemacetan di sekitar tempat tinggalnya dan kampus, baik kampus II maupun kampus III.

Tabel 1. Subjek Penelitian

\begin{tabular}{|c|c|c|c|}
\hline No & Nama & Prodi & Domisili \\
\hline 1 & $\begin{array}{l}\text { Qurrotul } \\
\text { Aini }\end{array}$ & $\begin{array}{l}\text { Ilmu } \\
\text { Komunikasi/ } \\
2016\end{array}$ & $\begin{array}{l}\text { Perumahan } \\
\text { Dinoyo }\end{array}$ \\
\hline 2 & $\begin{array}{l}\text { Izza } \\
\text { Amalia }\end{array}$ & $\begin{array}{l}\text { Sosiologi/ } \\
2015\end{array}$ & $\begin{array}{l}\text { Pakis, } \\
\text { Njabung, } \\
\text { Kabupaten } \\
\text { Malang }\end{array}$ \\
\hline 3 & $\begin{array}{l}\text { Alfiani } \\
\text { Rahmi } \\
\text { Putri }\end{array}$ & $\begin{array}{l}\text { Farmasi } \\
2016\end{array}$ & $\begin{array}{l}\text { Dusun } \\
\text { Rejoso, } \\
\text { Kecamatan } \\
\text { Junrejo,Kota } \\
\text { Batu }\end{array}$ \\
\hline 4 & $\begin{array}{l}\text { Faradilla } \\
\text { Rizqy } \\
\text { Amalia }\end{array}$ & $\begin{array}{l}\text { Sosiologi } \\
2015\end{array}$ & $\begin{array}{l}\text { Tumpang, } \\
\text { Kabupaten } \\
\text { Malang }\end{array}$ \\
\hline 5 & $\begin{array}{l}\text { Lena } \\
\text { Amanda }\end{array}$ & $\begin{array}{l}\text { Ilmu } \\
\text { Komunikasi } \\
2015\end{array}$ & $\begin{array}{l}\text { Malang, } \\
\text { Mergoutomo }\end{array}$ \\
\hline 6 & $\begin{array}{l}\text { Yusril } \\
\text { Rahmat } \\
\text { Hakim }\end{array}$ & $\begin{array}{l}\text { Ilmu } \\
\text { Pemerintahan } \\
2017\end{array}$ & Merjosari \\
\hline 7 & $\begin{array}{l}\text { Ahmad } \\
\text { Nurul } \\
\text { Huda } \\
\text { Pratama } \\
\text { Putra } \\
\end{array}$ & $\begin{array}{l}\text { Ilmu } \\
\text { Pemerintahan } \\
2017\end{array}$ & Merjosari \\
\hline 8 & Iqbal & $\begin{array}{l}\text { Keperawatan } \\
2018\end{array}$ & Singosari \\
\hline 9 & $\begin{array}{l}\text { Adinda } \\
\text { Eva }\end{array}$ & $\begin{array}{l}\text { Keperawatan } \\
2018\end{array}$ & $\begin{array}{l}\text { Perumahan } \\
\text { Graha } \\
\text { Dewata } \\
\text { Malang }\end{array}$ \\
\hline 10 & Amel & $\begin{array}{l}\text { Keperawatan } \\
2018\end{array}$ & Dinoyo \\
\hline
\end{tabular}

Kesepuluh subjek penelitian mengaku selalu terimbas kemacetan ketika berangkat dan pulang dari kampus, terutama ketika mereka pulang dari kampus atau setelah beraktivitas di kampus. Terlebih subjek dipilih dan diambil dari kampus II Universitas Muhammadiyah Malang dan Kampus III Universitas Muhammadiyah Malang.

$$
\text { Kampus } 2 \text { Universitas }
$$

Muhammadiyah Malang terletak di Jalan Bendungan Sutami nomor 188 Malang. Berlokasi dekat dengan beberapa 
kampus, di antaranya adalah berdekatan dengan Universitas Brawijaya, Universitas Negeri Malang dan Universitas Islam Negeri Maulana Malik Ibrahim Malang. Selain itu, kampus 2 Universitas Muhammadiyah Malang juga dekat dengan 2 Mall yaitu Malang Town Square dan Transmart Malang. Selain itu, kampus 2 Universitas Muhammadiyah Malang juga dekat dengan 2 sekolah yaitu Mts Negeri 1 Malang dan MAN 2 Malang. Hal di atas mengakibatkan seringnya terjadi penumpukan dan kepadatan lalu lintas terutama jika memasuki jam kerja. Seperti kita ketahui, saat ini jam aktif perkuliahan di seluruh indonesia sama yaitu dimulai jam 07:00 dan berakhir pada jam 16:00. Hal tersebut membuat ketika pada pagi dan sore hari terjadi penumpukan kendaraan, terutama kendaraan pribadi. Hal tersebut diperparah jika sudah memasuki jam pulang sekolah di 2 sekolah MTsN 1 dan MAN 2 Malang di mana sebagian besar siswa 2 sekolah tersebut dijemput menggunakan mobil pribadi dan kendaraan pribadi lainnya.

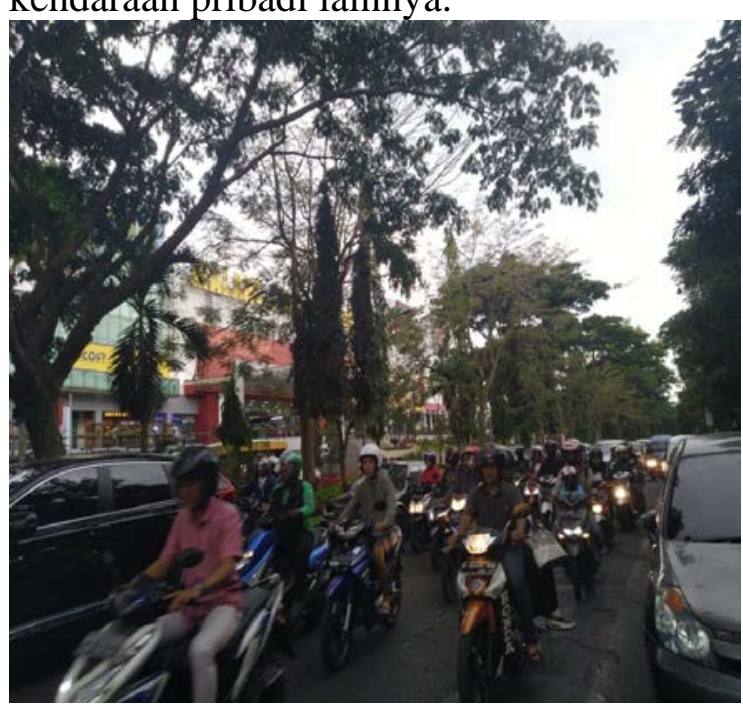

Foto 1. Kemacetan di jalan veteran (depan Malang Town Square)

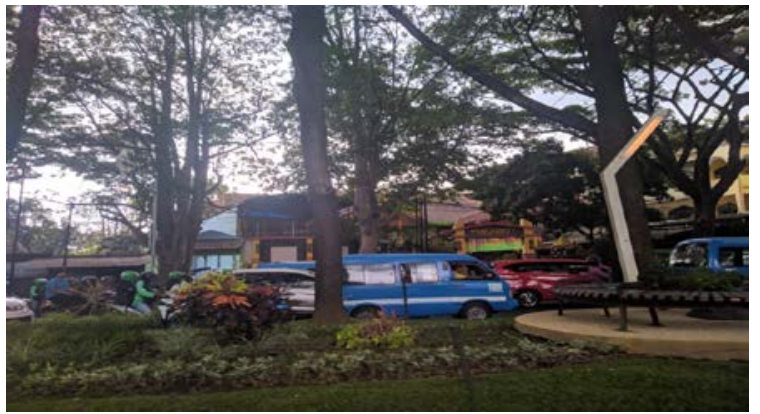

Foto 2. Kemaetan di jalan veteran (depan MtsN 1 dan MAN 2 Malang)

Kampus 3 Universitas

Muhammadiyah Malang berlokasi di Jalan Raya Tlogomas nomor 246 Malang. Berlokasi dekat dengan Universitas Islam Malang, juga dekat dengan Mall Dinoyo dan Sengkaling Kuliner. Jalan utama kampus 2 Universitas Muhammadiyah Malanng juga merupakan jalur penghubung antara Kabupaten Malang dan Kota Malang menuju Kota Batu sehingga merupakan salah satu jalan dengan lalu lintas yang padat di Kota Malang terutama pada akhir pekan.

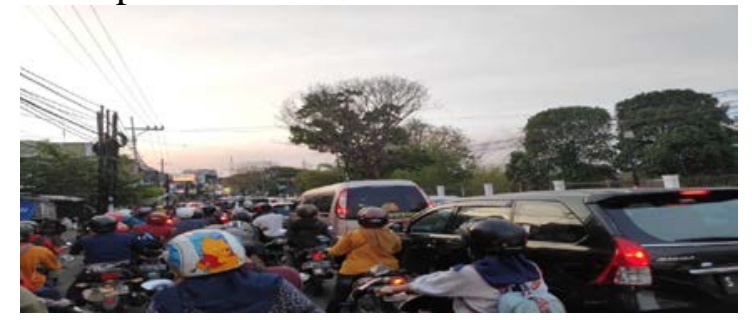

Foto 3. Kemacetan di Jalan Raya Tlogomas kampus 3 UMM

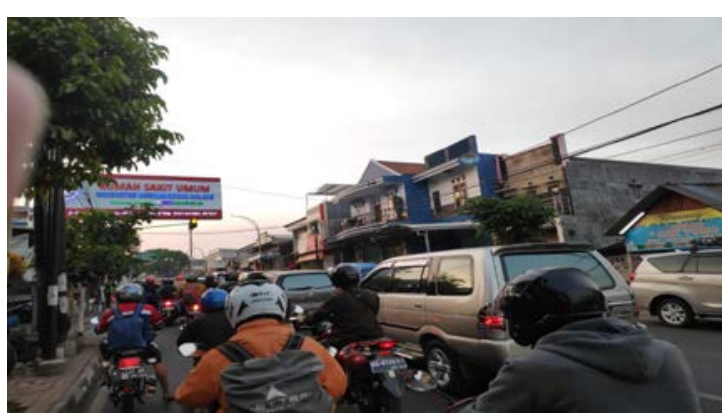

Foto 4. Kemacetan di Jalan Raya Tlogomas ( depan RS UMM ) 
1. Persepsi Tentang

Kemacetan: penyebab kemacetan

Dari data yang diperoleh dari wawancara dengan 10 Subjek penelitian terkait dengan kemacetan di Kota Malang, 8 sepakat dengan jawaban bahwa kemacetan di Kota Malang disebabkan karena banyaknya volume kendaraan bermotor. Sementara, 2 subjek penelitian mengatakan bahwa penyebab kemacetan di Kota Malang bukanlah semata-mata disebabkan karena jumlah kendaraan bermotor yang ada di kota Malang, tetapi lebih kepada pengaturan lalu lintas dan karena banyaknya kampus dan tempat wisata yang ada di Kota Malang.

Dari semua subjek penelitian yang peneliti ambil, ditemukan 2 fakta menarik terkait dengan urgensi persoalan kemacetan. 2 fakta tersebut adalah bahwa hanya 1 subjek yang mengatakan bahwa kemacetan adalah hal yang sangat penting untuk diatasi dan harus melibatkan semua pihak termasuk dirinya terutama dengan statusnya sebagai mahasiswa.

Fakta berikutnya adalah yang mayoritas dijawab oleh subjek penelitian, bahwa kemacetan di Kota Malang ini sudah sewajarnya terjadi di Kola Malang sebagai kota yang sedang berkembang, Kota Wisata dan Kota Pendidikan. Sehingga kemacetan adalah sesuatu yang mau tidak mau harus diterima sebagai efek samping dari ketiga hal tersebut di atas.

$$
\begin{aligned}
& \text { 2. Persepsi Tentang } \\
& \text { Kemacetan: } 3 \text { tahap } \\
& \text { dialektis } \\
& \text { Dalam teori Konstruksi Sosial }
\end{aligned}
$$
yang dikemukakan oleh Peter L Berger, setiap konstruksi lahir melalui 3 tahapan: Internalisasi, Objektivasi dan Eksternalisasi. Sehingga dalam penelitian ini, persepsi mahasiswa Universitas Muhamamdiyah Malang tentang kemacetan di Kota Malang juga melalui 3 tahapan tersebut.

a). tahap eksternalisasi. Pada tahapan ini, mahasiswa Universitas Muhammadiyah Malang sudah mengetahui kondisi lalu lintas di Kota Malang sejak mereka pertama kali memasuki Kota Malang. Begitu juga bagi yang merupakan warga asli Kota Malang, kemacetan yang terjadi sudah mereka lihat sejak mereka menempuh pendidikan di tingkat menengah atas (SMA/sederajat). Selain itu, persoalan kemacetan tidak pernah diperbincangkan dan dibahas menjadi isu penting di kalangan mahasiswa, sehingga persoalan kemacetan tianggap sebagai hal yang taken for granted dan tidak mendesak untuk dibahas.

b) tahap objektivasi. Pada tahapan ini, mahasiswa Universitas Muhammadiyah Malang mendapatkan stock of knowledge dari berbagai pemberitaan di berbagai media tentang kemacetan di kota kota besar di Indonesia. Semua kota besar hampir mengalami permasalahan yang sama yaitu masalah transportasi dan kemacetan. Dibandingkan antara kotakota lain dengan kondisi di Kota Malang, sama-sama mengalami kemacetan dan hal itu kemudian dianggap sebagai hal yang wajar. Ditambah banyak aspek yang menyebabkan padatnya lalu lintas di kota besar terutama di Kota Malang yaitu 
pertambahan

kendaraan

sementara

volume kendaraan bermotor

berbanding lurus dengan

volume mahasiswa yang ada di Kota Malang.

c) tahap internalisasi. Pada tahapan ini, mahasiswa Universitas Muhammadiyah Malang akhirnya mengambil sikap yaitu menganggap kemacetan di Kota Malang adalah karena dampak dari besarnya volume kendaraan. Volume kendaraan merupakan dampak dari banyaknya mahasiswa yang ada di Kota Malang yang mana hal itu merupakan efek yang ditimbulkan dari banyaknya jumlah Perguruan tinggi di Kota Malang. Maka, kemacetan adalah suatu hal yang tidak bisa dielakkan dari pertumbuhan suatu kota, termasuk Kota Malang yang sedang bertumbuh menjadi kota pusat pendidikan, pusat pariwisata dan pusat ekonomi.

\section{Kesimpulan}

Dari temuan yang diperoleh, dapat diketahui bahwa persepsi Mahasiswa Universitas Muhammadiyah Malang tentang kemacetan adalah bahwa kemacetan merupakan sesuatu yang wajar terjadi di Kota Malang. Hal ini sesuai dengan pengetahuan subjek tentang informasi yang diperoleh tentang kemacetan. baik informasi tersebut didapatkan melalui membaca maupun informasi tersebut diterima melalui lingkungan sekitar. Segala informasi terkait dengan kemacetan tersebut diobjektivikasi dan akhirnya terinternalisasi dalam diri subjek yang kemudian tercermin dalam sikap dan tindakan subjek yang tetap saja menggunakan kendaraan pribadi dalam kesehariannya meskipun mereka mengetahui bahwa kemacetan salah satunya disebabkan oleh jumlah kendaraan yang semakin banyak.

\section{Referensi}

Adisasmita, Sakti Adji., Perencanaan Pembangunan Transportasi. Yogyakarta, Graha Ilmu. 2011

Berger, L Peter dan Thomas Luckmann, Tafsir Sosial Atas Kenyataan, risalah tentang sosiologi pengetahuan, LP3ES, Jakarta, 2012

Damsar, Prof.Dr, Dr. Indrayani, Pengantar Sosiologi Perkotaan. Kencana, Jakarta,2017

Ekawati, Natalia Niken, Kajian Dampak Pengembangan Pembangunan Kota Malang Terhadap Kemacetan Lalu Lintas (Studi Pada Dinas Perhubungan Kota Malang) Jurnal Administrasi Publik (JAP), Vol. 2, No. 1, Hal. 129-133.

Haryono, Persepsi Masyarakat Tentang Kemacetan Lalu Lintas di Jakarta Jurnal Manajemen Transportasi \& Logistik - Vol. 05 No. 03, November 2018.

Pertiwi, Anna Aga, Pengaruh Keberadaan Parkir dan Pedagang Kaki Lima Terhadap Biaya Kemacetan Dan Polusi Udara di Jalan Kolonel Sugiono Malang Jurnal Rekayasa Sipil / Volume 5, No.3 tahun 2011 